\title{
'O Papo Já Foi Dado, Agora a Responsa é de Vocês': estratégias discursivas de policiais civis para orientação da conduta juvenil
}

Rachel Paula de Souza Machadoa Nalayne Mendonça Pinto ${ }^{b}$

Este artigo se propõe a refletir sobre o programa Papo de Responsa, criado pela Polícia Civil do Estado do Rio de Janeiro. O programa tem como principal objetivo conversar com jovens nas diversas escolas no estado do Rio de Janeiro. Embora atenda diferentes públicos, seu alvo é atingir os jovens, promovendo neles, autorreflexão, responsabilidade por seus atos, prevenção de possíveis atos delituosos e a produção moral do bom cidadão. Desta forma, os policiais são convidados pelas escolas e vão até os alunos promovendo o papo. Através da pesquisa de campo, desenvolvida nesta pesquisa, notou-se, que para produzir o bom cidadão, dispositivos morais são acionados ao longo das falas dos policiais, reproduzindo um senso comum moral. Estes discursos serão apresentados e analisados ao longo do artigo.

Polícia civil, Juventude, Moralidades, Bom cidadão.

A Polícia Civil do Estado do Rio de Janeiro possui um programa chamado Papo de Responsa. O programa conversa com diferentes segmentos da sociedade, desde que sejam solicitados, no entanto, seu

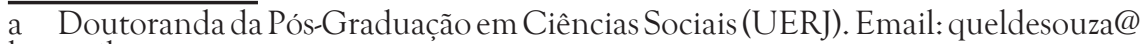
hotmail.com.

b Professora Associada da Pós-Graduação em Ciências Sociais e do Departamento de Ciêncas Sociais (UFRRJ). Email: nalaynempinto@gmail.com. 
principal objetivo, é conversar com adolescentes e jovens nas escolas públicas e privadas em todo o estado. Então, a partir do convite da escola, os policiais começam a desenvolver sua metodologia, que será explicitada adiante. O Papo de Responsa foi acompanhado ao longo da pesquisa de mestrado. A pesquisa é um estudo sociológico que foi realizado com auxílio de ferramentas metodológicas tais como: trabalho de campo com método observacional - com intuído de acompanhar os encontros do Papo Responsa, optou-se por ir aos encontros e ficar em silêncio, observando e registrando toda a dinâmica dos encontros; quadro de referência teórico-analítica - investigação com perspectiva compreensiva onde envolve a reconstrução dos sentidos subjetivos das ações e falas proferidas pelos sujeitos envolvidos no curso da ação (Weber 2001). Além disso, ao longo deste período foram feitas três entrevistas com policiais que atuam no programa, a partir de um roteiro semi-estruturado

A pesquisa teve como objeto as estratégias discursivas de orientação da polícia civil aos jovens. Como objetivo, buscou compreender a atuação do programa nas diversas escolas, identificar e analisar os discursos e moralidades, processos e metodologias produzidas pelo Papo de Responsa, durante a aproximação com as juventudes.

A partir da pesquisa de campo e entrevistas, percebeu-se, que os policiais que compõem o grupo, acreditam que é possível de fato produzir discursos que vão atingir os jovens, afetando sua conduta, como uma forma de papel redentor para uma possível carreira criminal juvenil. Neste sentido, observou-se uma frase constantemente repetida nos discursos dos policiais: "O nosso papo não é moralista e nem acusatório". O que fez saltar às reflexões, o que viria a ser um papo moralista para os policiais, e como estes discursos carregados de valores morais, estavam sendo proferidos ao passo que eram negados pelos policiais.

Estas reflexões inspiraram o presente artigo, que visa trazer relatos e falas do trabalho de campo e das entrevistas feitas durante a pesquisa, e ainda contribuir com análises acerca desta produção de discursos 
morais a partir de um empreendedorismo policial que visa a orientação das condutas juvenis.

\section{A criação do Papo de Responsa}

Vale aqui apresentar o que é o Papo de Responsa, como se deu a sua criação e como funciona a sua metodologia. O programa Papo de Responsa foi criado em 2003, por dois policiais ${ }^{1}$ da Polícia Civil do Estado do Rio de Janeiro, com o objetivo de aproximar jovens da polícia, ou, segundo eles, "aproximar pessoas de pessoas". Como relatou um policial participante do programa: "não é com arma na mão e dando tiro que se resolve”. Então, a estratégia deles é: "abaixar as armas e levantar a voz". Este mesmo policial me relatou que estão certos de que é com a juventude que eles devem trabalhar. Sobre a criação do programa, o Fundador A, relatou em entrevista:

Então assim, é o meu óculos, né? Talvez eu seja, talvez não, certamente eu sou a única pessoa que pode contar essa história do início ao fim, do início até agora, né? Não necessariamente do início ao fim. Então assim, dentro de mim, essa história nasce na minha segunda operação policial, com trocas de tiros com meninos, né? porque eles eram meninos atirando na gente, e nós fazendo o mesmo. Chegamos perto dos corpos dos meninos, tinham três corpos, os fuzis tavam [sic] quentes ainda, cápsulas de munição quanto você quisesse, e três meninos mortos, um tinha 16, um tinha acabado de fazer 18 e um tinha 19. Naquele momento ali me bateu uma intranquilidade. Assim, eu vi no rosto de alguns policiais orgulho, e não era orgulho porque a gente tinha tirado a vida de alguém, era orgulho porque na cultura policial por vezes a gente acredita que a missão tá [sic] cumprida, então são menos três bandidos, são menos três armas de grosso calibre, são menos munições, então a missão tá [sic] cumprida. Eu vi no rosto de alguns outros policiais indiferença e não era indiferença porque a gente deixou de amar, era indiferença porque aqueles não foram os primeiros não seriam os últimos e a vida precisa seguir, e na minha cabeça uma intranquilidade muito grande. (Entrevista com o Fundador A, 2018).

Portanto, o referido programa é voltado para adolescentes e jovens, embora não seja esta a faixa etária exclusiva. Trabalham com 
escolas a partir do nono ano ensino fundamental do segundo ciclo, ensino médio, faculdades, ONGs, ou qualquer outro grupo organizado que os solicitar, seja de iniciativa privada ou pública. Trabalham ainda buscando trazer um espaço que, segundo os agentes, promova diálogos descontraídos com o grupo que os solicitou, a respeito da prevenção do uso de drogas, da responsabilidade com seu corpo e com suas atitudes e consequências, ou, como foi dito, do 'bem viver' de maneira geral. A seguir, a metodologia e a entrada do programa Papo de Responsa nas escolas serão abordadas, analisando os discursos e práticas dos policiais nas interações com as juventudes.

\section{Entrada na escola}

Os encontros dos policiais com os jovens podem acontecer em palestras isoladas, como também um ciclo com cinco encontros, sendo esta, a metodologia ideal para os policiais. A primeira etapa é uma reunião entre os coordenadores e professores da escola e alguns policiais escalados. Esta reunião é chamada de Papo com os professores, onde ocorre uma primeira conversa. Neste momento, os policiais pedem licença aos professores para que possam falar com os alunos. Além disso, levantam informações sobre as demandas dos alunos que participarão do Papo. Em seguida ocorre o Papo com os alunos, onde os policiais vão até a escola e conversam sobre o tema salientado pela direção ou coordenação da mesma. No terceiro encontro, os alunos vão para o que se chama de visita à Cidade da Polícia. Após a visita, acontece mais um Papo com os alunos na escola, onde estes podem apresentar uma espécie de seminário dentro do tema, levantando a discussão do assunto que já vem sendo abordado. Porém, vale salientar que mesmo os policiais tendo me falado a respeito deste passo, durante todo o período em que acompanhei as atividades, não percebi a ocorrência desta etapa. Pude observar que esta etapa tem ocorrido cada vez menos por conta da grande demanda da agenda do programa e das escolas, o que leva ao adiantamento da última etapa. A última etapa é o Papo com a família, onde o jovem chama alguém que o re- 
presente, para ir até a escola conversar com os policiais do programa. Desta forma se completa o ciclo.

A segunda etapa, 'Papo com os alunos', por se tratar de uma interação bem direta entre os alunos e os policiais, permite que os policiais exponham seus discursos e ousam algumas falas dos alunos. Neste momento os policiais vão até a escola fardados para conversar com as turmas de alunos escolhidos pela direção e coordenação da escola. Para o programa é importante o uso da farda pelo impacto que causa nos alunos, segundo a policial:

$\mathrm{Na}$ minha percepção, eles de início são bloqueados, independente da classe social. Eles têm bloqueio com a polícia, e por isso a gente vai fardado e armado, é um dos motivos, da gente ir vestido de preto, com arma, pra eles nos olharem e nos identificarem como polícia, porque quando a gente vai de roupa comum e distintivo, não é a polícia, por mais que eles saibam, é um civil sem ser policial. E aí a gente bota o uniforme mesmo pra mostrarmos que somos policiais e eles olharem e já saberem quem nós somos. Somos corruptos, bandidos, assassinos, que é assim que é a imagem da polícia, o estereótipo da polícia. E aí, pra minha surpresa, eu achava que era difícil mudar isso mas não é. Durante duas horas é o necessário pra quebrar esse estereótipo que eles criam. Porque eles são muito influenciáveis, muito influenciáveis... É lógico que eu não posso comparar uma vivência de 14 anos de uma favela que a referência é o traficante, com duas horas eu falando ali, mas ainda assim você vê que eles são facilmente influenciáveis. (Entrevista com a inspetora Marcela, 2017).

Muito importante, o uniforme é muito simbólico, uma coisa é ir de uniforme outra coisa é ir sem uniforme. [...] Com os professores não, você pode estar com uma camisa gola polo nossa, né? E tal [sic], sem problema, com a direção também, até mesmo à paisana, né? Como a gente é policial, com o distintivo pendurado, não tem problema. Mas com os alunos sem dúvida. (Entrevista com o Fundador A, 2018).

Os policiais usam a farda no Papo de Responda por alguns motivos, como relatado. Eles utilizam a farda para gerarem todo tipo de reação, fazem questão de usá-la nos papos com os alunos, já que de início causa um impacto nos estudantes, e confere legitimidade para 
os policiais. Segundo Goffman (2002), os indivíduos aprendem seus papeis sociais e dentro destes papeis desempenham suas representações. Para o autor, as interações sociais, como as promovidas pelo Papo de Responsa, são fundamentais para que cada um represente seu papel social. Neste sentido, a vestimenta, os trejeitos, gírias, armas e distintivos dos policiais, são essenciais para a representação de policial que se pretendem naquele momento.

Como os policiais acreditam no papel que desempenham, segundo suas próprias falas, eles estão sendo sinceros nas suas atuações. Este desempenho expressivo padronizado é denominado por Goffman como fachada. "Fachada, portanto, é o equipamento expressivo de tipo padronizado intencional ou inconscientemente empregado pelo indivíduo durante a representação." (Goffman 2002:29). Portanto, se faz necessário notar que o uso das fardas dos policiais, está inteiramente relacionado com sua atuação nas interações com os jovens.

Voltando agora para estas interações nas escolas, vale lembrar que quem acompanha a visita é uma coordenadora, ou orientadora pedagógica, que sinaliza quando há algum aluno usuário de drogas, ou que trabalha na boca de fumo, sinaliza se há alguém que passou por problemas de exposição na internet, pelo vazamento de fotos íntimas e pessoais. Porém no geral, o que elas costumam apontar são os alunos 'problemas"', estes que se envolvem de algum modo com o uso de drogas ou os que são considerados agressivos e violentos. Além da escola sinalizar, os policiais ao longo da sua palestra, dizem conseguir identificar quais são os adolescentes usuários de drogas.

Ainda que nas falas os policiais, sobretudo os fundadores, indiquem um intuito de levar os alunos a questionarem e refletirem sobre sua realidade, de motivar os alunos a continuarem estudando, e alcançarem seus objetivos, à medida que interagem com os alunos, proferem discursos que evidenciam um conjunto de valores e moralidades do que seja um jovem de comportamento adequado segundo a polícia e o senso comum. Nisto se encontra uma contradição importante na compreensão dos discursos e práticas dos policiais do programa. 
Como se percebe em muitas falas, os policiais evidenciam sempre que não são moralistas ou acusatórios, no entanto, suas falas estão carregadas de valores próprios de 'Poliçópolis ${ }^{3}$ '. No entanto, vale marcar aqui a existência desta contradição, percebida em diversos discursos, como se pode notar no relato de um Papo com os alunos do nono ano, em uma escola do município do Rio de Janeiro, localizada na Zona Norte.

Ao começar a falar, a policial não teve a atenção que geralmente tem nas escolas. Ela é comunicativa e muito carismática, então conseguir se comunicar bem com os jovens, não costuma ser um problema para a mesma. Porém, neste dia, os alunos, que por serem do nono ano, eram mais novos que a faixa etária preferencial dos policiais e estavam muito agitados e falando muito alto. Desta forma, a policial começa a conversa, diferente do que ocorre no geral, falando de forma dura com os estudantes.

O que vocês acham que a polícia está fazendo aqui na escola de vocês? A gente tá cansado de prender meninos e meninas com a cara de vocês, é a cara de vocês na ponta do meu fuzil, são vocês que mais morrem. É a cara de vocês que mais passa fome, que tá no DEGASE. Quarenta e oito mil jovens morreram ano passado. Jovens, negros, de baixa escolaridade e pobres, jovens que não querem escutar, jovens que lá na ponta eu pego. Eu era muito pobre, muito pobre, vi que a única saída era estudar. Com muita dificuldade me formei e passei para polícia, pra acabar com o tráfico e dar tiro. Mas conheci o Papo através de um amigo [...] e entrei pro Papo. (Fala da policial aos alunos, 2018) (Grifo nosso).

Ao falar sobre os confrontos armados com jovens a policial fala:

Falhou muita ciosa quando eles trocaram tiro com a gente, falhou escola, família, religião, eles nos odeiam porque contaram uma história pra eles!" (Fala da policial aos alunos, 2018).

Neste momento, os alunos começam a prestar mais atenção na policial. E ela segue:

O verdadeiro traficante tá na cobertura, o filho dele vai nadar com golfinho, o filho dos outros fuma o baseadinho e banca tudo isso.

Tô aqui pra tirarem aquela coisa do cavalo do rosto e virem que o 
mundo não é o bairro de vocês, o mundo é muito maior. Porque pra pegar na arma não precisa coragem, mas pra mudar a realidade precisa. (Fala da policial aos alunos, 2018) (Grifo nosso).

Então, a policial conclui para então passar a palavra para o seu colega:

Gente, comecei brigando com vocês porque vocês não querem ouvir, não quero pegar vocês na ponta do fuzil lá fora. A gente vacila mesmo nessa idade, mas temos que ouvir. Toda escolha tem consequência, não dá pra [sic] plantar tomate e querer abacaxi. O Papo não é acusatório e nem moralista. Vocês podem ir muito além disso, não deixa a galera que tá lá em cima pisar em vocês não. Você pode, só depende de você. É claro que pra nossa realidade é muito mais difícil. Bate no peito e assume teu problema vou passar por isso e vou resolver meu problema. Não querem que vocês sonhem! Porque se vocês sonharem vocês vão longe, hoje eu vejo que teve resultado. Hoje eu vejo que teve resultado, o atalho vem fácil mas vai fácil. (Fala da policial aos alunos, 2018).

Importa destacar que nos relatos de campo, quer no Papo com professores, quer no Papo com os alunos, os policiais afirmam a importância do Papo de Responsa para atuar de forma preventiva na redução e orientação do comportamento juvenil.

Neste sentido, vale lembrar que ao final das conversas com os alunos os policiais sempre repetem a frase: "O papo nós já demos, agora a responsa é de vocês”, o que novamente imputa a responsabilidade das escolhas potencialmente criminosas feitas pelos jovens. Em determinada circunstância, em uma conversa informal, perguntei à uma policial do programa se eles não levam em consideração ao falarem com os jovens, determinadas situações de vulnerabilidades nas quais eles podem estar inseridos. A policial respondeu que levar estas possibilidades em consideração é o mesmo que justificar os crimes que os jovens cometem.

\section{O empreendedorismo policial e as orientações das condutas juvenis}

O programa Papo de Responsa se percebe como um programa de prevenção, se distanciando do papel institucional da polícia civil, que 
é uma polícia investigativa. Deste modo desenvolvem um tipo de empreendedorismo policial no trabalho com os jovens visando produzir o 'bom cidadão'. É neste momento que os discursos morais permeiam as falas dos policiais. Ao observar os discursos e entrevistas e ainda recorrendo a literatura a respeito da prevenção de crimes cometidos por jovens, nota-se que neste intento, diversos estigmas são acionados e reforçados, justificando a necessidade da orientação moral oferecida ali por aqueles policiais.

\section{Prevenção do desvio}

[...] Mas, sem dúvida nenhuma a prioridade é atender as escolas porque é o nosso maior foco na ponta, aquela idadezinha ali entre os 14 e os 24 é o nosso público alvo nas prisões, cometendo crime, então eles são nosso público alvo também na prevenção. (Entrevista com a Inspetora $\left.\mathrm{Marcela}^{4}, 2017\right)$.

Como já salientado até aqui, o Papo de Responsa é visto como um programa de prevenção por seus integrantes e por autoridades da área da segurança. Porém, importa recorrer aos estudos da área de polícia, para visualizar como a prevenção é compreendida e posta em prática, segundo esta literatura.

Sendo assim, 'O papel da polícia no sistema de justiça criminal no Brasil' é discutido no livro 'A polícia diante da infância e da juventude: infração e vitimização', de autoria de Cerqueira \& Prado (1999)5. O autor discute o papel que é atribuído a polícia no que tange o trabalho de prevenção e repressão da delinquência juvenil. Isto, de acordo com as recomendações das Nações Unidas e do Estatuto da Criança e do Adolescente. Então, o capítulo salienta a importância de haver uma maior integração no sistema de justiça criminal juvenil articulando seus próprios órgãos, que neste estudo se trata da polícia, tribunais e organizações de tratamento para os jovens.

O serviço de prevenção policial, segundo o estudo, está relacionado à repressão de atividades criminosas através das patrulhas, investigação de crimes, combates à vícios, evitar acidentes de trânsito e 
prevenção de delitos juvenis. A polícia deve fiscalizar a formação do jovem e vigiar a conduta daqueles que são menores de idade.

No entanto, de acordo com o estudo, a polícia brasileira por não ter o costume de acumular experiências preventivas, é mais influenciada pelo combate ao crime. Além do mais, no estudo trazem estas integrações como importantes para a eficácia da prevenção policial, mas compreendem que no Brasil não ocorre tamanha integração de setores como sugerido no início, como polícia, comunidade, justiça criminal juvenil, organizações de tratamento.

Jacqueline Muniz, ao tratar sobre o assunto prevenção, no artigo 'Despolitização da segurança pública e seus riscos' (2012), levanta efeitos danosos que esta visão causa para a própria cidadania, quando o rumo político não é bem definido. Para a autora, um destes efeitos é que a cidadania torna-se regulada pelo Estado, uma despolitização por conta do que Muniz chama de cultura do controle. Esta concepção vai concedendo cada vez mais poder coercitivo ao Estado, indo na contramão da democracia. Segundo o artigo isto pode acarretar em uma privatização da segurança e das polícias, gerando megaoperações e um discurso economicista contábil de segurança, que possibilitem contabilizar números da mão invisível do livre mercado. Desta forma, a política de prevenção fica condicionada ao que vale mais a pena de acordo com a lógica do retorno do investimento feito

Esta avaliação de riscos como forma de prevenção, segundo Muniz, traz a contradição de empoderar indivíduos em situação de vulnerabilidade, por meio da negação de sua identidade, ou seja, os indivíduos considerados vulneráveis precisam deixar de lado elementos constitutivos da sua identidade, para que então percam os traços que os estigmatiza. Deste modo, administrar riscos implica em identificar as fontes de ameaças e indo além das mesmas. No entanto, isto confere ainda mais mecanismos de controle por parte do Estado, reforçando estereótipos. Sendo assim, a tentativa de prevenção, acaba por levar a penalização antecipada dos indivíduos, a segregação e discriminação que visava reverter. Isto acarreta, segundo Muniz (2002), 
em uma cruzada moralista, legitimada pela necessidade recorrente de ampliar o campo da vigilância, aumentando o controle social ${ }^{6}$ e os mecanismos estatais ou privados.

Assim como recomenda Cerqueira \& Prado (1999), Jacqueline Muniz (2012), afirma que as ações de prevenção, por seu caráter preditivo, necessitam apropriar-se melhor dos estilos de vida e dos usos dos espaços coletivos dos grupos sociais. Para tanto, importa definir a prevenção à ordem da segurança pública em termos concretos a respeito produção de controle, vigilância e regulação da ordem pública (Muniz 2012).

As recomendações acerca de como pode funcionar o trabalho de prevenção e seus desdobramentos, foram vistos a partir dos estudos da segurança pública. É possível perceber como a forma de prevenção na 'segurança cidadã', exposta por Muniz (2012), acarreta em reproduções de estigmas e eliminação ou penalização antecipada dos indivíduos. Portanto, adiante, será visto como para as então autoridades da segurança pública e para os policiais civis do Papo de Responsa a prevenção é percebida, através da produção do bom comportamento, da obediência, da responsabilidade e sobretudo pela negação ao uso de drogas.

O Papo de Responsa é percebido como um programa de prevenção. Isto não apenas pelos policiais civis que o compõe, mas também por autoridades como o então Chefe da Polícia Civil, Rivaldo Barbosa, o Secretário de Segurança, General Richard Nunes, ambos ocuparam os respectivos cargos, durante a intervenção militar na segurança no estado do Rio de Janeiro em 2018. O que confere ao programa uma legitimidade, embora tenham algumas dificuldades por ausência de reconhecimento no interior da polícia civil.

Neste sentido, o Fundador A relata em entrevista como percebe este trabalho preventivo desempenhado dentro da polícia civil e como lida com críticas dos demais policiais a respeito do programa.

Como se atuar nas consequências do problema fosse resolver o problema tanto quanto atuar nas causas. Na verdade a única 
forma de resolver o problema é atuar nas causas e não nas consequências. Quando o Papo caminhas nas escolas, universidades e tal, a gente consegue ter uma visão um pouco mais próxima da atuação nas causas. Mas a causa mesmo só vai ser resolvida quando a gente conseguir diminuir essa enorme desigualdade social na qual a gente tá [sic] inserido. Não tem possibilidade da gente viver esse gap social que a gente vive e acreditar que a gente vai resolver os nossos problemas com o tiro, com mais arma. Alguns policiais conseguem entender isso, hoje mesmo tive uma conversa com alguns ali, eles mesmo falando da importância do programa, porque eles entendem que a nossa marca institucional se valoriza e que nós, no Papo de Responsa, conseguimos fazer com que as pessoas normalmente cidadãos, meninos e meninas, homens e mulheres consigam ter acesso a uma polícia civil a um trabalho de polícia civil que antes não teriam ou só teriam pelos jornais, e aí não vale a pena. Só que eu quando recebo as críticas, o que fica muito claro pra mim, é uma falta de entendimento, a partir do momento que um policial desses conversar com a gente só um pouquinho, ou que ele for assistir um Papo, ele vai falar 'Caramba! Eu achava que vocês faziam outra coisa!'. Mas alguns não estão interessados em querer saber porque querem continuar numa valorização das suas razões, e outros talvez não tenham tido oportunidade ainda, mas eu acho que tem um processo em andamento. (Entrevista com o Fundador A, 2018).

Neste sentido, pode-se dizer que o Papo de Responsa, com suas orientações, visa prevenir o comportamento desviante. Aquele indivíduo que como visto no segundo capítulo, é descrito por Becker (2008), como desviante de um padrão socialmente estabelecido por um grupo, trata-se do indivíduo rotulado de tal modo por aqueles que o cerca, já que na concepção destes, o outsider, se desviou de alguma, ou várias regras do grupo.

O Papo de Responsa mantém um caráter de empreendedorismo policial, com dispositivos morais, que remetem à Howard Becker (2008), no que tange aos empreendedores morais. Howard Becker, em seu livro 'Outsiders: Estudos de sociologia do desvio', analisa os empreendedores morais, que são aqueles indivíduos criadores ou impositores de regras. Para o autor, o protótipo do criador de regras é o reformador cruzado, que opera com uma ética absoluta. Impondo sua 
moral aos outros, acredita que se as pessoas fizerem o que é certo será bom para elas. Extraem poder da sua posição superior na sociedade, o que legitima sua posição moral. Quando bem sucedida, a cruzada moral, acarreta em regras.

O Papo de Responsa enquanto um programa de prevenção e aproximação remete a filosofia do policiamento comunitário. Segundo o Manual de policiamento comunitário (2009), produzido pelo Núcleo de Estudos da Violência, da Universidade de São Paulo, em parceria com o governo federal, o papel da polícia civil no policiamento comunitário, está relacionado a sua função de polícia investigativa e judiciária, contribuindo nas estratégias de inteligência com os seus dados a respeito do local que receberá a ação. Enquanto a polícia militar, tem a função de inibir os atos criminosos a partir da sua presença visível, por isso o uso do uniforme é importante para seu trabalho. Neste sentido, percebe-se que o trabalho do Papo de Responsa se assemelha com os deveres de atuação da polícia militar, o que eles fazem questão de negar, visto que como policiais atuantes na segurança pública, estão cumprindo seu papel de redução de futuros enfrentamentos com os jovens a quem atendem.

"O policiamento criminal é geralmente reconhecido como o âmago do mandato policial e a principal justificativa para a existência do estabelecimento policial. Realmente, para a maioria dos policiais, somente combater o crime é o 'verdadeiro trabalho da polícia', mesmo que na prática real apenas uma pequena parte de todas as atividades policiais envolvam o controle do crime" (Bittner 2003:30-31).

Desta forma, o policiamento criminal é a justificativa para o estabelecimento policial, o que traz a mente os discursos e modo de policiamento dos policiais do Papo de Responsa, que se percebem exercendo o trabalho de polícia, que é, na concepção de Bittner (2003), e dos próprios policiais, controlar o crime. À medida que os policiais falam para os jovens que é bom que eles ouçam o papo ali, já que se forem pegos na rua em alguma atitude ilícita não terá conversa, eles acreditam estarem controlando/reduzindo o crime. 


\section{A produção moral do bom cidadão}

Os policiais do programa Papo de Responsa, acreditam ser possível afetar a vida dos jovens e interferir na sua conduta e em possíveis carreiras criminais, através dos seus discursos nas escolas. Portanto, é necessário conceituar o que está sendo compreendido como moral neste artigo, através da literatura clássica das ciências sociais ${ }^{7}$. E ainda salientar o que está sendo percebido como moral policial, a partir da pesquisa empírica.

Segundo Durkheim, as normas morais não se tratam de meras ordens, antes, tem uma finalidade desejável para quem é destinada. Assim, as normas morais são o bem para aquele povo. Toda sociedade, para o autor, é uma sociedade moral, e através da crença das pessoas na ascendência moral de determinados papeis sociais, a moral é reproduzida. Existe uma moralidade construída na consciência coletiva que acaba sendo um senso comum geral que predomina e se impõe como uma moralidade homogênea. Servindo de amalgama para toda a sociedade (Durkheim 2008:218).

Este conceito de moral é utilizado como forma de se analisar a produção moral do bom cidadão por parte do Papo de Responsa, no sentido pensar como a polícia reproduz a ideia de senso comum moral. Podendo notar como os discursos policiais carregam o dever, intrínseco a noção de bem e de um conjunto de normas e regras, uniformes para toda sociedade, a serem seguidas.

Além deste conceito de moral, importa ressaltar como é compreendida a noção de moralidade policial a partir de tantas observações e entrevistas, analises de discurso, feitas durante todo o período de pesquisa empírica. Portanto, a moral policial trazida a conhecimento, a partir do Papo de Responsa, gira em torno do legalismo policial. Os policiais intencionam que os alunos sigam as leis estritamente, a partir de uma moral conservadora/ legalista do que vem a ser as leis e o seu cumprimento. Portanto, a produção moral do bom cidadão, está relacionada, antes de qualquer ferramenta estratégica do programa, como produzir nos adolescentes e jovens uma moral que o faça obe- 
decer às leis e manter seu comportamento e atitudes dentro do que é 'socialmente esperado'.

Desta forma, algumas estratégias realmente são traçadas para que se produza o bom cidadão, como se pode perceber no relato do Fundador A. Para ele é fundamental na conversa com os jovens, trabalhar a autoestima dos mesmos, para que eles possam acreditar em si e correr atrás dos seus objetivos.

Um bom exemplo dessa história da autoestima e de como a gente é capaz de mexer com eles com uma boa conversa, né? Com o espírito bem aberto, né? Com a reação humana bem estabelecida de uma forma saudável, tava no Sul Fluminense, numa escola muito cheia de dificuldades, uma escola pública, mas uma escola viva, a despeito de todas as dificuldades. E eu perguntei pra eles quantos achavam que iam pra universidade, um dos meninos levantou a mão, não eram muitos, normalmente de cem, meia dúzia levanta o braço quando a gente faz esse tipo de pergunta, que é diferente das escolas particulares onde todos levantam o braço, né? Eles tem certeza que irão à universidade, e um dos meninos levantou o braço e falou que queria fazer medicina, e eu faço sempre uma brincadeira pra mexer um pouco com o brio deles, mas eu passei boa parte do papo chamando o menino de doutor. Porque ele falou que queria ser médico então eu tava ali, depois de ter feito a brincadeira que eu faço pra mexer com o brio deles eu fiquei chamando ele de doutor, doutor, doutor, doutor. Acho que passou umas duas semanas ele me escreveu, e ele falou assim, olha, queria te agradecer muito e queria te dizer o seguinte, a escola inteira tá me chamando de doutor agora, então mesmo que eu não quisesse fazer medicina, eu ia decepcionar tanta gente agora, que hoje eu só consigo me enxergar de fato fazendo medicina. Assim, isso não tem preço, e é um menino de escola pública, a gente sabe que no nosso país pra alguém se formar em medicina é certamente uma das carreiras mais difíceis e hoje o menino não se vê imaginando outra coisa. Se ele tá acreditando que isso pode acontecer, isso pode acontecer, né? Então o desafio que a gente tem com esses meninos e meninas é fazer com que eles percebam que qualquer coisa independente das dificuldades que eles enfrentem pode acontecer desde que eles determinem. Não vai ser fácil, mas eles podem se determinar a isso, então, em termos de tema, do que a gente é capaz de fazer e de entregar pra eles, eu acho que não tem nada mais fundamental do que quando a gente mexe com a auto estima, quando a gente mexe 
com a possibilidade do que eles não conseguiam nem enxergar, e do que eles são capazes de enxergar a partir do nosso movimento, é óbvio, diretamente falar sobre todos os temas que a gente fala, surte efeito, né? molecada toma decisões diferentes, pensa diferente, mas eu acho que o ponto básico assim é relações humanas. Eles são capazes de se enxergar de um outro jeito e de enxergar os outros, e são capazes de criar uma luz, um movimento interno de crença, de que a partir das nossas histórias, sejam as histórias pessoais, sejam as histórias que a gente conta, que eles são capazes de fazer um outro movimento que não esse que eles estão fazendo. (Entrevista com o Fundador A, 2018) (Grifo nosso).

Neste sentido, com a intenção de trabalhar a autoestima e estimular o jovem a acreditar em si e no seu futuro, os discursos dos policiais possuem um caráter liberal, em que basta acreditar e trabalhar em prol do objetivo que o jovem vai conseguir alcançá-lo, independente das circunstâncias a sua volta. $O$ programa Papo de Responsa, como pode ser observado na fala do Fundador A, acima transcrita, visa em suas interações com os estudantes, fazer com que eles reflitam em suas atitudes. Geralmente os policiais partem de perguntas que estimulem os jovens a refletirem em sua vida. O Papo de Responsa conta com as respostas e reflexividades dos seus ouvintes, para que estes possam mudar suas práticas e agirem em conformidade com a moral proposta pelos policiais em seus discursos.

Como a nossa metodologia, ela vai em cima desse processo de reflexão, eu preciso que você pense junto comigo, porque aí que eu atuo no teu chip, eu não quero que você repita o que eu disse, eu quero que você reflita o que eu disse, por isso a gente não diz que droga é ruim, a gente dá elementos pra você poder tomar a sua decisão. Se sua decisão for de não, bacana, e se sua decisão for de sim, é a sua decisão. Por isso a gente pintou um jargão já de muito tempo que o papo a gente dá mas a responsa é de cada um. (Entrevista com o Fundador A, 2018).

Desta forma, para compreender a moralidade do Papo de Responsa, é necessário levar em consideração a sociologia da moral abordada por Alexandre Werneck (2012), que percebe morais e valores como objeto de observação; e assim trabalha as formas como as moralidades 
coletivas ou individuais são postas em contraste com as moralidades dos demais atores. No caso do Papo de Responsa, os policiais se colocam como um programa que não é moralizador e que não está ali para falar o que é certo e o que é errado fazer, mas querem que os alunos reflitam sobre suas escolhas. No entanto, não existe nenhuma pessoa que falando por uma instituição ou não, esteja livre de valores morais. Em pergunta sobre como construiu um diálogo com os estudantes, livre de valores morais, o Fundador A, responde:

Na verdade isso é uma utopia, né? É como uma imprensa parcial, não existe. Mas serve pra gente desejar que exista, né? Serve pra gente desejar. A palavra mágica é dizer sem dizer, é ter a sutileza de não parecer juízo de valor, a gente tem os nossos moralismos, né? Os nossos valores, mas o que a gente faz é tentar apresentar várias versões, né? Por isso a gente não diz: 'Não usa droga porque é ruim', o menino vai se ele colocar a disposição de experimentar o baseado ele ai ver que ele vai sentir um relaxamento, ou que aquele problema, aquela dor que ele tava sentindo deu uma diminuída. A mãe dele faz isso usando frontal, rivotril, e o moleque sabe disso, porque a gente não pode subestimar a capacidade de um menino deste, entendeu? De uma menina. Mas não tá livre de moralismos, a gente só coloca isso numa caixa mais centro, né? Ao invés do meu moralismo ser mais à direita, ou mais à esquerda, o que eu faço é colocar esse fio de moralismo no meio e tentar fazer com que ele não apareça, pra gente poder falar mais livremente sobre tudo, né? A menina da favela, ela tem o moralismo dela, que muitos julgariam do lado de cá, que é mais baixo que o de alguns, por conta da roupa que ela usa ou da forma que ela se comunica e tal, mas não significa dizer que ela não tem o moralismo dela. Se eu for falar cobre isso ali, eu preciso ter habilidade pra falar com ela que eu respeito qualquer mulher que queira usar um shortinho curtíssimo e dançar da forma que quiser dançar se ela for uma mulher. Mas se ela for uma menina, eu preciso ter um olhar diferente para com ela, por que ela tá em formação. Isso é um pensamento que tem moralismo, mas eu to explicando pra ela que como mulher, ela pode usar a roupa e escutar a música que ela quiser escutar, inclusive se ela desejar transar com dois homens, se esse for o desejo dela, se ela tiver feliz com isso sexualmente, se agradar aos homens e vice versa, se ela quiser ter uma relação com uma mulher, tá tudo bem, ela tem esse direito. Já uma menina precisa ser cuidada por todos nós, porque ainda tá num processo de formação, tá carrega- 
do de moralismo isso, mas ao mesmo tempo eu to explicando pra ela qual é o ponto. Não tem nada a ver com as suas escolhas como mulher, por favor faça isso, mas pra uma criança eu preciso ter um cuidado diferente, e não é por conta da lei, é porque há muito tempo os nossos mais antigos faziam isso nas aldeias, né a gente cria, tem um ditado africano muito bonito que diz: 'é preciso uma aldeia inteira pra educar uma criança ${ }^{8}$. (Entrevista com o Fundador A, 2018) (Grifo nosso).

Assim, explicita-se que durante as falas há uma orientação de valores, normas e condutas que são apresentados aos jovens, e percebe-se a contradição já mencionada, quando os policiais dizem não desejarem fazer discursos morais. Então, perguntando sobre um resultado ideal que o programa espera, a policial entrevistada respondeu que interessa ao programa orientar e conduzir o 'bom cidadão'.

O ideal, a utopia seria o bom cidadão. Na origem, o Papo foi criado por conta da droga, hoje em dia a gente nem vê a droga como principal problema, acho que Hitler não usava droga e matou milhões, então assim, a droga em si, ela é um causador da violência, aumenta muito, mas hoje o ideal seria o respeito ao próximo, fazer na tua vida as melhores escolhas, que a consequência vem, eu não posso plantar tomate, eu falo isso sempre pra eles, não posso plantar tomate e querer colher abacaxi. Então, o ideal seria eles ouvirem e fazerem as melhores escolhas. $\mathrm{O}$ bom cidadão falo do bem viver, fazendo as melhores escolhas, o certo e o errado é muito diferente de pessoa pra pessoa né. A gente pergunta isso direto: 'Fumar um baseadinho, só fumar, é crime? - Não, não, fumar não!' que tem a lei do usuário, eles acham que não é crime. É crime, você tá susten[...] tá no ciclo da violência, do tráfico. E aí muitos, uma menina inteligentíssima num papo falou assim: 'É crime? Eu não acredito!' Ela chorava, e falou 'Eu sou usuária de maconha, fumo a muito tempo, mas eu achava que como eu uso, tava fazendo mal só a mim!' A menina argumentou assim num nível altíssimo, 'então assim se eu cultivar eu não tô?' Não, cultivo é tráfico, e é pior, você vai pegar de 5 a 15 anos. Então a gente conversa, a utopia, o ideal, seria todos entenderem o que é o melhor pra sua vida, não é que sejam todos iguais, é diferente, são diferentes mas com escolhas corretas. O melhor de cada um, dentro do correto, da corretude. Esse seria o ideal para o Papo todo, antes a gente era muito metódico na questão da droga, não a gente tem que ser 
contrário e tal, hoje a gente tá mais aberto a várias informações e a gente tá na ideia das melhores escolhas, vamos falar com eles sobre as melhores escolhas. Então a gente tenta voltar sempre pra esse objetivo: o ideal seria eles nos ouvirem, ouvirem os pais, ouvirem os professores, ouvir quem eles tem por ouvir, de experiência, mas sempre tomar as melhores decisões. $\mathrm{O}$ ideal seria esse. Utopia eu acho, não dá pra ser assim, não vai ser, um desafio gigante da gente ter esse resultado. (Entrevista com a inspetora Marcela, 2017) (Grifo nosso).

Pode se observar, então, que o programa propaga um ideal de sociedade, de 'bom cidadão' baseado em uma concepção moral relacionada a obediência às normas legais, aos policiais, aos responsáveis, professores. Está ligado ao afastamento dos jovens das drogas e dos comportamentos indesejáveis. Afinal, o Papo foi dado, a Responsa é do jovem.

Os policiais civis participantes do Papo de Responsa, como representantes do Estado, detentor do monopólio da força, em suas atividades com os alunos, com todos estes discursos já mencionados, visam a produção do bom cidadão. Isto lhes confere um caráter civilizador, nos termos de Elias, onde: "O processo civilizador constitui uma mudança na conduta e sentimentos humanos rumo a uma direção muito específica." (1993:193). Desta forma, o processo civilizador altera as condutas humanas rumo a civilização. Esta mudança, segundo Elias (1993), ocorre de dentro para fora, mas também de fora para dentro, o que demonstra que os indivíduos tem agência na estrutura social que está se modificando e consciência nas mudanças individuais também. O autocontrole é um novo ethos civilizatório, onde os indivíduos devem converter seus instintos/ impulsos naturais em instintos sociais, alterando seu gestual e comportamento. Trata-se de um contexto de internalização do autocontrole.

Ao passo que o Papo de Responsa tem como resultado ideal a produção do bom cidadão, as mudanças na conduta, a internalização dos impulsos e o autocontrole, ele está fazendo com que os estudantes passem por uma espécie de processo civilizador, onde os jovens ficam 
algumas horas ouvindo os discursos e moralidades dos policiais e para que o evento seja bem sucedido é necessário que ocorra mudanças na vida destes jovens.

Neste sentido, as etapas do ciclo do Papo de Responsa são importantes para os policiais que visam construir o bom cidadão e mudar as condutas juvenis. Neste momento, será descrito um relato da terceira etapa da metodologia do programa, a visita à Cidade da Polícia.

Quando os policiais vão às escolas, eles convidam os alunos para fazerem uma visita à casa deles, que é a Cidade da Polícia. Dizem que foram à casa dos alunos que é a escola, e agora estes devem retribuir a visita. Os policiais fazem questão de dizer que o espaço da Cidade da Polícia é um lugar público, feito com dinheiro público, de todos e para todos. Então eles têm a oportunidade de irem lá se 'apropriarem' deste espaço. No momento, será relatada uma destas visitas acompanhadas no decorrer da pesquisa. A visita ocorreu com duas turmas do 9o ano do ensino fundamental de uma escola municipal, localizada na Zona Oeste do Rio de Janeiro, os alunos aparentavam ter cerca de 14 anos de idade. A inspetora de polícia Marcela, me relatou que a diretora havia contado que metade de seus alunos na escola eram 'bandidos' e a outra metade 'prostituta'.

Marcela levou os alunos para que conhecessem as dependências da Cidade da Polícia, cada delegacia especializada, explicando qual era a necessidade dessas delegacias e tirando algumas dúvidas dos alunos sobre o funcionamento, como por exemplo, se essas delegacias mesmo sendo lá dentro, funcionam como as outras, e sim, funciona atendendo a comunidade, como qualquer outra Delegacia de Polícia. Os alunos estavam ansiosos por ver as dependências da Polinter, onde esperavam e ver as celas, e os indivíduos que lá se encontravam.

Ao chegarem lá em frente, os policiais Marcela e Tiago explicaram que antes os alunos podiam entrar nas dependências, sem tirar foto das pessoas presas e nem estabelecerem nenhum tipo de contato. Porém, Marcela contou que em determinada circunstância, um aluno falou para um indivíduo que se encontrava preso: "Aí se ferrou hein!”, 
fazendo sinais com as mãos. $O$ preso reagiu cuspindo no menino, o que levou o delegado a proibir a entrada dos alunos na Polinter. Enquanto isso, chegou a viatura que leva as pessoas presas para o complexo de Bangu. Então os alunos presenciaram a retirada dos detentos da Polinter, se encaminhando à viatura.

Uma estudante ao perceber o que estava ocorrendo, começou a chorar muito e se afastou, dando costas para o que estava ocorrendo. Sinalizei para a professora, pois a menina não me parecia estar bem. A professora me respondeu dizendo que o irmão da menina havia sido preso e depois morto, então ela estava se deparando com a realidade, o que segundo a professora era algo positivo.

Tiago então reuniu o grupo falando que este tipo de coisa (pessoas sendo presas) pode ocorrer com qualquer um. Desde que façam más escolhas, fazendo coisas erradas. Ele relembrou, "lembram o que nós conversamos com vocês na escola, a responsa é de vocês, vocês podem escolher o caminho bom, fazendo o que é certo, ou podem escolher fazer coisas erradas, mas aí vai dar nisso aí! (apontando na direção da Polinter)”. A professora que os acompanhara, perguntou: "Eles também podem ir presos caso façam alguma coisa né?" Tiago respondeu: "No caso de menores de idade, nós não chamamos de presos, mas são apreendidos e depois levados para as instituições de menores como Padre Severino."

Após falar com os alunos, Tiago me contou que antes de serem proibidos de entrarem na Polinter, por medidas de segurança para os alunos, eles colocavam os adolescentes na cela, para que cada um sentisse o peso de como é, em muito menor escala, encontrar-se preso.

Passado isso, os alunos entraram nas dependências do esquadrão antibomba, parte referente a CORE, Tropa de Elite da Polícia Civil do Rio de Janeiro, como explicou Marcela. Então, o chefe do esquadrão os recebeu, passou um vídeo mostrando algumas imagens deles isolando locais, detonando bombas, ou então desativando-as. Depois o grupo viu um robô que é utilizado nas atividades. Os alunos fizeram perguntas, como por exemplo, se já haviam errado alguma vez, e o 
agente respondeu que nunca erraram. Pois nesse caso, um policial só pode errar uma vez, porque ocorrido o erro, o mesmo morre.

O grupo então foi avisado que não poderia ir à cidade cenográfica (favelinha, como os policiais chamam), onde queriam muito ir. Lá, ocorrem as simulações de operações, e no momento estava acontecendo treinamento, então não poderiam ir até lá. Viram apenas uma parte de longe. Após, os adolescentes foram levados ao centro esportivo, onde teriam uma aula como se eles tivessem passado na prova da polícia e agora estivessem na academia de polícia.

Tiago me explicou que essa aula era muito legal, pois trabalhava com os alunos o respeito ao professor, trabalho em equipe, espírito de liderança e disciplina. Então, os alunos que quiseram fazer a aula, entraram no tatame, e Fernando, professor de educação física da academia de polícia, se apresentou, mudou os alunos de lugar e não os deixou falar, dando um tratamento, ainda que muito minimizado, como se estivessem em uma aula real do treinamento inicial dos policiais.

Fernando, já de início explicou que a palavra aluno, é um vocábulo oriundo de 'sem luz', ou seja, ali, quem detinha a luz e o conhecimento era o professor. Então ele fez com que todos sentassem da mesma forma, sempre falando "vamos padronizar." Perguntou quem gostaria ser o representante da turma, ignorou todos aqueles que levantaram a mão e escolheu exatamente o que desviou o olhar, sem perguntar se o mesmo tinha interesse em ser representante. $\mathrm{O}$ aluno foi obrigado a ser o líder da turma.

Então começou a desenvolver as atividades, e qualquer erro no exercício, qualquer palavra ou gestual fora de hora, os alunos tinham que pagar flexões ou abdominais, sentar, deitar e levantar rápido, como se estivessem com uma arma na mão. Fernando ensinou que para 'pagarem' pelo erro ele iria perguntar: "Só a dor?" Então os alunos responderiam: "Gera compreensão!", e ele reproduziu isso muitas vezes em voz alta e ativa com os alunos. A aula acabou com Fernando falando sobre a importância de trabalharem juntos, que agora eram uma família, se um sofresse, todos também sofreriam. $O$ coordenador 
da área de educação do Papo de Responsa, o Fundador B, foi ao encontro de Tiago e disse: "Esse Fernando é um showman!" Pois de fato, o professor é muito carismático e sua aula dinâmica.

Tiago me explicou que muitos policiais dentro da Cidade da Polícia, não concordam com o trabalho do Papo de Responsa. Acham inútil, Mas Tiago disse que a estratégia deles é exatamente esta: "abaixar as armas e levantar a voz", me disse que estão certos que é com a juventude que eles devem trabalhar. Não é com arma na mão e dando tiro que se resolve.

Com este breve relato, percebe-se que em todas as conversas sempre há o reforço da ideia da responsabilização do jovem por seus atos. No centro desportivo, a intenção dos policiais é fazer com que os alunos realmente internalizem os princípios que são passados, como o respeito a hierarquia, o que remete a disciplina como uma forma de poder sobre o corpo, que é individualizante, segundo Foucault (2005).

\section{Construção do medo}

A partir do relato acima descrito, mas também de todo o decorrer dos capítulos anteriores, percebe-se que o uso de ameaças, como estar na ponta do fuzil, encontrar um dos policiais do programa na rua, ou ainda a possibilidade de entrar em uma cela na Polinter, além dos esforços para enfatizar a hierarquia existente, como na aula no centro desportivo, são fatos que fazem parte de uma construção do medo por parte dos policiais para com os adolescentes. No entanto, é importante perceber que boa parte dos jovens atendidos pelo Papo de Responsa, são jovens que, como já abordado, sofrem o processo de sujeição criminal (Misse 2010). Carregam o perfil do jovem tomado pela polícia como elemento suspeito (Musumeci \& Ramos 2005). Ainda segundo as autoras, os jovens produzem representações sociais e opiniões acerca das abordagens policiais e seus contatos com policiais. Os jovens compreendem as abordagens como um dispositivo de controle social da vida urbana, visto que, as investidas policiais são o elo, a relação entre o Estado e os segmentos da juventude, principalmente, da 
juventude periférica. Surge o conflito e o medo dos jovens em relação à polícia. Os jovens rotineiramente são abordados nas ruas de maneira hostil e sem justificativa. A relação de jovens negros e pobres com a polícia, é uma relação conflituosa e de insegurança. Enquanto jovens de classe média e alta, também passam por situações constrangedoras com a polícia, levando-os a terem uma relação de desconfiança e de tensões que geram medo da instituição policial.

A disseminação do medo como controle da vida urbana e garantia da ordem é percebida como estratégia desde muito tempo, segundo Batista (2003). A polícia no Rio de Janeiro, que desde o início foi criada para que a elite e a corte fossem protegidas, desde então teve seu inimigo bem delimitado. A polícia já mantinha um tipo de pessoas denominadas como classes perigosas e agiam de modo ostensivo, com a justificativa de prevenir crimes e manter a ordem. O Papo de Responsa, também visa prevenir que jovens cometam crimes. Há uma sensação de insegurança relacionada aos jovens pobres, principalmente se forem negros, presente na sociedade e em alguns discursos dos policiais, atribuindo a estes indivíduos, um rótulo que os criminaliza, fazendo com que os mesmos não tenham seus direitos respeitados, passem por situações de constrangimento e sejam alvos de operações polícias desrespeitosas e preconceituosas.

Ocorre a construção do medo nos discursos e práticas policiais no Papo de Responsa através de hierarquias, ameaças, a presença física do fuzil nas visitas às escolas. Porém, isto se torna justificável pela construção do medo que ocorre antes. $\mathrm{O}$ medo das "classes perigosas", que legitima desde as políticas de extermínio, até ameaças nas salas de aula.

Estas ameaças ocorridas nos discursos de todas as etapas do Papo de Responsa, com os alunos, produz o medo através da fala. Ao passo que os policiais em diversas circunstâncias, colocam os estudantes no lugar do criminoso, ele está abaixando a arma, levantando a voz e incutindo o medo. Para confirmar esta afirmação, algumas falas dos policiais serão retomadas. 
Os policiais que morreram, morreram em assalto. Em confronto, a polícia sempre ganha. A polícia vai matar! Eu sou policial e eu não vou perder nunca. (Fala do Fundador B, 2017).

Meu Papo não é moralizador, eu não disse que você não pode fumar. Você pode fumar, só que eu vou te prender. (Fala do policial, 2018).

Eu adoro arma, atiro muito bem! Espero não encontrar ninguém do outro lado! (Fala da inspetora Marcela, 2018).

A gente tá cansado de prender meninos e meninas com a cara de vocês. É a cara de vocês na ponta do meu fuzil, são vocês que mais morrem. É a cara de vocês que passa fome, que tá no DEGASE. 48 mil jovens morreram ano passado, jovem, negro, de baixa escolaridade e pobre. (Fala da inspetora Marcela, 2018).

Percebe-se como a produção do medo de estar 'do outro lado' ou de estar 'na ponta do fuzil' medo da 'polícia matar', é algo recorrente nos discursos dos policiais do programa, visando que estes jovens não cometam crimes e mantenham uma conduta responsável.

\section{Conclusão - 'o papo foi dado!'}

"O papo foi dado, agora a responsa é de vocês". Os policiais do programa repetem essa frase com frequência. Lembrando que cada indivíduo deve se responsabilizar por seus atos, visando sempre fazer as melhores escolhas. $\mathrm{O}$ que se visa com este discurso, é a produção moral do bom cidadão, a partir do empreendedorismo policial que o programa desenvolve. Produzem falas que dizem não ser morais, mas devido ao caráter legalista que estas falas carregam, se tornam discursos morais.

A moral como temática, perpassa toda a análise aqui apresentada, à medida que os discursos dos policiais do Papo de Responsa vão sendo expostos. Porém, convém ressaltar que a moral, a partir da sociologia da moral analisada por Werneck (2013), propõe a perceber morais como objeto de observação. Importa ressaltar ainda que, segundo o autor, a moral de cada indivíduo não se trata de uma repetição inconsciente. Membros do mesmo grupo social compartilham formas 
de compreender a vida, decisões, opiniões, no entanto, há agência reflexiva dos indivíduos ao reproduzirem a moral do grupo. Segundo Werneck, a moral é cognitiva, o que significa que os indivíduos podem criticar e distinguir entre o que é o bom ou não para eles. Desta forma a moral enquanto um dispositivo de agência permeia os discursos policiais, como pode ser notado ao longo do artigo.

Os discursos feitos pelos policiais do Papo de Responsa por vezes são carregados de exemplos, que fazem questão de colocar o jovem 'do outro lado da polícia', estando na sua mira, o que produz medo, visando que os jovens mantenham suas condutas aceitáveis. $\mathrm{O}$ programa 'faz o jovem viver' e regulamenta o modo como se dará esta vivência. Desta forma, importa analisar estes sentidos, valores e moralidades na construção da fala dos policiais, que visam produzir o Papo, afetando assim as juventudes com quem interagem.

\section{Notas:}

1 Estes policiais que criaram o programa serão aqui nomeados como: Fundador A e Fundador B. Os outros policiais citados ao longo do artigo receberam nomes fictícios.

2 'Sujeito construído na cultura escolar enquanto 'não aluno' em um processo atravessado por questões étnico-raciais, de classe e de gênero que se dá, necessariamente, nas interações conflituosas no ambiente escolar tendo em vista a manutenção da organização escolar estabelecida. O comportamento desviante é o primeiro critério a ser atendimento, entretanto, não é o único. O estigma do aluno-problema tende a ser produto da convergência entre pobreza, aspectos raciais e gênero na definição das regras e na definição do que é considerado subversivo, desestabilizador e perturbador." (Edson Gomes 'Aluno problema: uma proposta de análise da produção do estigma em escolas de um município da Baixada Fluminense'. Projeto de Qualificação do Doutorado do Programa de Pós Graduação de Educação - UFRJ, 2018:31)

3 Durante o trabalho de campo notou-se que este termo era utilizado recorrentemente pelos policiais para dizer que a polícia não é oriunda de outro planeta, chamado 'poliçópolis', antes, a polícia vem da sociedade. Esta ideia foi desconstruída pensando a partir das identidades e culturas institucionais que criam padrões e normas que permitem afirmar que policiais são oriundos de uma instituição, que no momento foi nomeada (aproveitando o uso nativo) como 'poliçópolis'. 
4 Vale lembrar que todos os nomes dos policiais citados são fictícios.

5 Nos anos 90 do século XX o Coronel da PMERJ Carlos Magno Nazaré Cerqueira publicou pelo ICC - Instituto Carioca de Criminologia uma Coleção de orientação e de textos fundamentais para a polícia; a coleção denominada 'Polícia Amanhã̃ foi financiada pela Fundação Ford e contou com 6 volumes. Trata-se de rara publicação para orientação e prática policial publicada no Brasil.

6 Neste sentido, encontram-se os estudos de Garland (2001), sobre as teorias do controle social. Segundo o autor, a criminologia caminhava em torno do bem estar social e da assistência aos indivíduos, porém, no período que ele chama de modernidade tardia, essa realidade mudou. O novo padrão de relações sociais, econômicas e a cultura, trouxeram também mudanças no âmbito da segurança e no modelo de controle social. Agora, o controle do crime gera lucros por ter parte com negócios privados e o Estado por sua vez, age buscando a vingança e a exclusão, característica que segundo Garland provém da justiça privada. Estas novas teorias do controle, assumem uma visão de mundo obscura e antissocial, visando um controle robusto através de estratégias da família, da comunidade e do Estado, que impunham limites e restrições efetivas (Garland 2001).

7 É necessário incorporar ao debate, a noção de moral segundo Didier Fassin, que orientou suas pesquisas para o que chamou de economias morais, sendo estas os jogos normativos e sociais que fundam práticas políticas. A partir de um artigo que visa refletir sobre as contribuições de Fassin, para a análise crítica das políticas de saúde dirigidas às populações vulneráveis, nota-se que o autor médico, sociólogo e antropólogo francês, estuda como os jogos normativos e sociais, entendidos como um tipo de moral, interfere na vivência de imigrantes de vários tipos como: ilegais, refugiados, fugitivos. Então, através da análise destes grupos e de suas relações com as políticas públicas e os modos sociais e morais de compreensão da questão do sofrimento que Fassin trabalha questões acerca de um governo humanitário (Vasconcellos \& Weintraub 2013).

8 De acordo com o Art. 4o do Estatuto da Criança e do Adolescente, o discurso do Fundador A é coerente com a lei. Sendo uma criança ou um adolescente, cabe ao Estado e a comunidade cuidar e dizer o que deve ou não fazer. Portanto, como menores de idade não devem se prostituir e usar drogas, então cabe a sociedade cuidar. http://www.planalto.gov.br/ccivil_03/Leis/L8069.htm.

\section{Referências:}

BATISTA, Vera M. 2003. Difíceis ganhos fáceis: Drogas e juventude pobre no Rio de Janeiro. Rio de Janeiro: Revan.

BECKER, Howard. 2008. Outsiders estudos de sociologia do desvio. Rio de Janeiro: Zahar.

BITTNER, Egon. 2003. Aspectos do trabalho policial. São Paulo: Editora da Universidade de São Paulo. 
CERQUEIRA, Carlos. 1999. A polícia diante da infância e da juventude: infração e vitimização. Rio de Janeiro: Instituto Carioca de Criminologia Freitas Bastos.

DURKHEIM, Émile. 2008. Da divisão social do trabalho. São Paulo: Editora Martins Fontes.

ELIAS, Norbert. 1993. O processo civilizador: Formação do Estado e civilização. Rio de Janeiro: Zahar.

ESTATUTO da Criança e do Adolescente. Página da Presidência da República, Casa Civil - Subchefia para Assuntos Jurídicos. (www.planalto.gov.br/ ccivil_03/Leis/L8069.htm; acesso em 10/01/2019).

FOUCAULT, Michel. 2005. Em defesa da sociedade. São Paulo: Martins Fontes.

GARLAND, David. The Culture of Control: Crime and Social Order in Contemporary Society. Chicago: The University of Chicago Press, 2001.

GOFFMAN, Erving. 2002. A representação do eu na vida cotidiana. Petrópolis: Editora Vozes.

GOMES, Edson. 2018. Aluno problema: uma proposta de análise da produção do estigma em escolas de um município da Baixada Fluminense. Projeto de Qualificação do Doutorado. Rio de Janeiro: UFRJ.

MISSE, Michel. 2010. "Crime, sujeito e sujeição criminal: Aspectos de uma contribuição analítica sobre a categoria 'bandido”. Lua Nova, 79:15-38.

MUNIZ, Jacqueline. 2012. Despolitização da segurança pública e seus riscos. Sociedade em perspectiva: Cultura, conflito e identidade. Rio de Janeiro: Grama Livraria e Editora.

MUSUMECI, L. \& RAMOS, S. 2005. Elemento suspeito abordagem policial e discriminação na cidade do Rio de Janeiro. Rio de Janeiro: Civilização Brasileira.

NEV/USP. 2009. Manual de Policiamento Comunitário: Polícia e Comunidade na Construção da Segurança. São Paulo: Núcleo de Estudos da Violência/ Universidade de São Paulo.

VASCONCELLOS, M. P. \& WEINTRAUB, A. 2013. "Contribuições do pensamento de Didier Fassin para uma análise crítica das políticas de saúde dirigidas a populações vulneráveis”. História, Ciências, Saúde, 20(3):10411055.

WEBER, Max. 2001. Metodologia das Ciências Sociais. São Paulo: Editora da Universidade Estadual de Campinas.

WERNECK, Alexandre. 2012. A desculpa: as circunstâncias e a moral das relações sociais. Rio de Janeiro: Civilização Brasileira.

2013. "Sociologia da moral como sociologia da agência". Revista Brasileira de Sociologia da Emoção, 12(36):704-718.

Abstract: This article proposes to reflect on the Papo de Responsa program, created by the Civil Police of the State of Rio de Janeiro. The main objective of the program is to talk to young people in different schools in 
the state of Rio de Janeiro. Although it serves different audiences, its aim is to reach young people, to promote there, self reflection, responsibility for their actions, prevention of possible acts and moral production of the good citizen. In this way, the police are invited by the schools and go to the students promoting the papo. Through field research, developed in this research, it was noted that to produce the good citizen, moral devices are triggered along the lines of the police, reproducing a common moral sense. These discourses will be presented and analyzed throughout the article.

Keywords: Civil police, Youth, Morality, Good citizen.

Recebido em Abril de 2019. Aprovado em Janeiro de 2020. 